\title{
Nutritive Appraisal of Various Wheat Varieties/Lines for Developing Biofortified Wheat (Triticum Aestivum L.)
}

\section{Abdullah $\mathbf{M}^{1^{\star}}$, Ahmad $\mathbf{J}^{1}$, Javed $\mathbf{A}^{1}$, Hussain $\mathbf{M}^{1}$, Shamim $\mathbf{S}^{1}$, Shair $\mathbf{H}^{1}$, Zulkiffal $\mathbf{M}^{1}$, Imtiaz $\mathbf{M}^{2}$, Owais $\mathbf{M}^{1}$ and $\mathbf{G u l n a z}^{\mathbf{1}}$}

${ }^{1}$ Wheat Research Institute, Ayub Agricultural Research Institute, Faisalabad, Pakistan

${ }^{2}$ International Maize and Wheat Improvement Centre (CIMMYT) Pakistan office, CSI building, NARC, Islamabad, Pakistan

\begin{abstract}
Essential micronutrients such as iron and zinc deficiencies affect more than two billion people globally especially the pregnant women and children below the age of five. Wheat, like many other staple cereals, contains low levels of the essential micronutrients iron and zinc. It contributes 13.1 percent to the value added in agriculture and 2.8 percent to GDP of Pakistan. National Wheat Breeding program at Faisalabad, Pakistan analyzed 240 samples of wheat varieties/lines both from irrigated and rainfed conditions. The analysis revealed that 1000 grain weight ranged from 23.9-50.2 in irrigated and 31-42.0 g in rainfed conditions while test weight range was found to be 59.9-75.8 (irrigated) and $64.5-79.9 \mathrm{Kg} \mathrm{hl}^{-1}$ (rain-fed). Protein and gluten content ranged between 12.0-16.1 \& 13-16.2 and 21-34 \& 21-38\% in irrigated and rainfed trial, respectively. Starch content was found to be 51.8-57.1 and 51.9-56.1\% in irrigated and rain-fed set, respectively. Falling No. (FN) values were recorded in the range of 352-814 in irrigated and 352-814 sec in the rain-fed set. Most of the varieties/lines had narrow range of $\mathrm{Zn}$ (3132.6 \& 31.2-33.9) and $\mathrm{Fe}(35-40$ \& 35-43 ppm) in irrigated and rainfed trial, respectively. In irrigated, conditions, cluster 3(5 genotypes) represented relatively high value of $\mathrm{Fe}$ and $\mathrm{Zn}$ contents while in rainfed condition, cluster 2 (31 genotypes) and cluster 3(15 genotypes) represented relatively high value $\mathrm{Zn}$. Statistical analysis of both sets showed gluten \& protein being directly correlated to each other, showing a positive correlation with $\mathrm{Fe} \& \mathrm{Zn}$ but a negative one with starch. In both sets, a direct correlation of $\mathrm{FN}$ with starch was observed only in rainfed set.
\end{abstract}

Keywords: Nutritive appraisal; Biofortified; Developin; Wheat

\section{Introduction}

Wheat production was estimated at 25.750 million tons during 2016-17 [1] which was surplus than country requirement and serves as an important indicator of food security. Annual consumption of wheat on per capita basis is $125 \mathrm{Kg}$ [2] and mostly it is consumed as chapatti (unleavened flat bread).

Wheat, like many other staple cereals, contains low levels of the essential micronutrients iron and zinc. Globally up to two billion people are victim of iron and zinc deficiencies, particularly in regions with predominantly cereal-based diets [3]. Nutritional considerations, therefore, are vital. It contributes 13.1 percent to the value added in agriculture and 2.8 percent to GDP of Pakistan.

Wheat crops play an important role in satisfying daily calorie intake in Pakistan, but they are inherently very low in $\mathrm{Fe}, \mathrm{Zn}$ and protein concentrations in grain, particularly when grown on $\mathrm{Fe}$ and $\mathrm{Zn}$-deficient soils. Wheat serves as an important dietary item of the people of Pakistan and accounts for nearly $843 \mathrm{Kcal} /$ capita/day of energy (37 percent of daily calories) and $22 \mathrm{~g} /$ capita/day of protein (37 percent of daily protein consumption). Therefore, it calls for quality depiction to determine nutritive value in respect of its intake.

Wheat was physico-chemically evaluated to find out its qualitative status in order to develop bio-fortified wheat which may be useful in overcoming $\mathrm{Fe}$ and $\mathrm{Zn}$ deficiency among vulnerable population. National Wheat Breading program based 240 samples of various wheat varieties/lines included in Irrigated and Rainfed National Uniform Wheat Yield Trials NUWYT) during 2016-17 were physico chemically analyzed for quality characteristics like 1000 grain weight, test weight, protein, starch, gluten, falling number, Fe and $\mathrm{Zn}$.

\section{Material and Method}

Protein was determined by Kjeldahl method (Instruction manual VELP Scientifica). Two grams sample was taken and added a tablet of digestion mixture and $10 \mathrm{ml}$ suphuric acid. Digested sample was diluted. After distillation sample was titrated against sodium hydroxide. Protein was determined after multiplying correction factor with nitrogen percentage. Starch by NIR instrument (instruction Manual Omeg Analyzer G) wheat sample was taken in hopper and used eighteen $\mathrm{mm}$ sample spacer for getting reading of starch content value [4]. Gluten content by glutomatic apparatus used in ISO-17025 certified CT Lab [5]. A 10 gram sample of flour weighed and placed into the glutomatic washing chamber on top of the polyester screen. The sample was mixed and washed with a 2 percent salt solution for 5 minutes. The wet gluten was removed from the washing chamber, placed in the centrifuge holder and centrifuged. The residue retained and passed through the screen was weighed. $\alpha$-amylase activity by falling number apparatus being used in ISO-17025 certified CT Lab [6]. About seven gram sample of ground wheat was weighed and combined with $25 \mathrm{ml}$ of distilled water in a glass falling number tube with a stirrer and shaken to form slurry. As the slurry was heated in a boiling water bath at 100 Degree Celsius and stirred constantly, the starch gelatinized and formed a thick paste. The time took the stirrer to drop through the paste was recorded as the falling number value. 1000 grain weight was determined by counting the grains from seed counter, Numigral II (Chopin, France). After counting 1000 grains, their weight was done with the help of balance (GR 200, Japan) used in the ISO-17025 Certified cereal technology laboratory. Test weight of the wheat samples was assessed with test weight apparatus. A bowl of one liter capacity was filled with wheat

*Corresponding author: Abdullah M, Durum Wheat Technologist, Wheat Research Institute, Ayub Agricultural Research Institute, Jhang Road, Faisalabad Punjab, Pakistan, Tel: 00923009603260; 00923314458900; Fax: 0092419201685; E-mail: abdmsc@yahoo.com

Received April 25, 2018; Accepted July 17, 2018; Published July 20, 2018

Citation: Abdullah M, Ahmad J, Javed A, Hussain M, Shamim S, et al. (2018) Nutritive Appraisal of Various Wheat Varieties/Lines for Developing Biofortified Wheat (Triticum Aestivum L.). J Food Process Technol 9: 743. doi: 10.4172/21577110.1000743

Copyright: @ 2018 Abdullah M, et al. This is an open-access article distributed under the terms of the Creative Commons Attribution License, which permits unrestricted use, distribution, and reproduction in any medium, provided the original author and source are credited. 
Citation: Abdullah M, Ahmad J, Javed A, Hussain M, Shamim S, et al. (2018) Nutritive Appraisal of Various Wheat Varieties/Lines for Developing Biofortified Wheat (Triticum Aestivum L.). J Food Process Technol 9: 743. doi: 10.4172/2157-7110.1000743

Page 2 of 4

grains and by weighing with the help of this apparatus test weight was measured. Test weight of the wheat samples was assessed with test weight apparatus. A bowl of 1 liter capacity was filled with wheat grains and by weighing with the help of this apparatus, test weight was measured. Iron and Zinc were analysed by Atomic Absorption Spectrophotometer (Model: 969, Unicam Limited, Cambridge, UK); Furnace (Model: GF 90, Unicam Limited, Cambridge, UK) with temperature range 250-600 $\pm 10^{\circ} \mathrm{C}$ and Furnace Auto-Sampler (Model: FS 90, Unicam Limited, Cambridge, UK) through AOAC Method No. 985. 35 [7].

\section{Results and Discussion}

National uniform wheat yield trials (Irrigated and Rain-fed) samples were physico- chemically analysed for various quality characteristics. Analysis of the various quality parameters revealed; 1000 grain weight ranged from 23.9-50.2 g in Irrigated and 31.0-42.0 g in rain-fed condition while test weight range was found to be 59.9-75.8 (Irrigated) and 64.5$79.9 \mathrm{Kg} \mathrm{hl}^{-1}$ (rain-fed). Higher grain weight and test weight of varieties are related to higher production of wheat and are helpful to improve food security in the country [8]. Protein content ranged between 12.016.1 and $13.0-16.2 \%$ in irrigated and rain-fed trial, respectively while gluten was found to be in the range of 21-34 \% in irrigated set and 21-38 $\%$ in the rain-fed set. Higher values in combination with other foods [9] may be helpful to cover Protein Energy Malnutrition (PEM) Starch contents were found to be 51.8-57.1 and 51.9-56.1\% in irrigated and rain-fed set, respectively and falling number value was recorded in the range of 352-814 sec in irrigated and rain-fed set. Falling number value recorded as more than 250 seconds represent sound wheat which may again indirectly related to improve food security. Most of the varieties/ lines had narrow range of minerals i.e. 31-32.6 and 31.2-33.9 ppm $\mathrm{Zn}$ in irrigated and rain-fed trial while Fe ranged from 35-40 in irrigated and $35-43 \mathrm{ppm}$ in rain-fed conditions, respectively [10]. In irrigated and rain-fed set, statistical analysis showed positive correlation of gluten with protein and $\mathrm{Zn}$ while it was negatively correlated with starch. Protein had positive correlation with $\mathrm{Zn}$ and negative correlation with starch (Tables 1 and 2).

Similarly iron depicted positive association with protein and $\mathrm{Zn}$. Additionally in irrigated condition, association between gluten and iron was positive while iron had negative association with starch $[11,12]$. The vector view of the Biplot (Figures 1 and 2) provides a concise summary of the interrelationships among the traits and genotypes. The traits values are joined to the origin by side lines. Values with short spokes do not exert strong interactive forces. Those with extended spokes put forth well-built interaction. The values representing the traits are connected to the origin. In irrigated condition (Figure 3), cluster 1, cluster 2 and cluster 3 consisted of 33, 22 and 5 genotypes, which represent $55 \%, 37 \%$ and $8 \%$ of total genotypes, respectively. Cluster 1 exhibited relatively high value of protein and gluten while low value of starch percentage. Cluster 2 had relatively high value of grain weight while notably lowest value of falling number. Cluster 3 represented relatively high value of $\mathrm{Fe}$ and $\mathrm{Zn}$ contents. While in rainfed condition (Figure 4), cluster 1 , cluster 2 and cluster 3 consisted of 14, 31 and 15 genotypes, which

\begin{tabular}{|c|c|c|c|c|c|c|c|}
\hline & GW & Tw & Protein & Starch & Gluten & FN & $\mathrm{Fe}$ \\
\hline TW & 0.022 & & & & & & \\
\hline P-Value & 0.868 & & & & & & \\
\hline Protein & $\begin{array}{l}0.110 \\
0.402\end{array}$ & $\begin{array}{l}0.160 \\
0.223\end{array}$ & & & & & \\
\hline Starch & $\begin{array}{c}-0.156 \\
0.234\end{array}$ & $\begin{array}{l}0.203 \\
0.121\end{array}$ & $\begin{array}{c}-0.471^{\star \star} \\
0.000\end{array}$ & & & & \\
\hline Gluten & $\begin{array}{l}0.094 \\
0.477\end{array}$ & $\begin{array}{l}-0.021 \\
0.872\end{array}$ & $\begin{array}{c}0.683^{* *} \\
0.000\end{array}$ & $\begin{array}{c}-0.615^{* *} \\
0.000\end{array}$ & & & \\
\hline FN & $\begin{array}{l}-0.230 \\
0.077\end{array}$ & $\begin{array}{l}0.027 \\
0.838\end{array}$ & $\begin{array}{l}0.205 \\
0.116\end{array}$ & $\begin{array}{c}-0.125 \\
0.339\end{array}$ & $\begin{array}{c}-0.034 \\
0.798\end{array}$ & & \\
\hline $\mathrm{Fe}$ & $\begin{array}{c}-0.086 \\
0.515\end{array}$ & $\begin{array}{l}0.252 \\
0.052\end{array}$ & $\begin{array}{c}0.691^{* *} \\
0.000\end{array}$ & $\begin{array}{c}-0.225 \\
0.084\end{array}$ & $\begin{array}{l}0.402^{*} \\
0.001\end{array}$ & $\begin{array}{l}0.227 \\
0.081\end{array}$ & \\
\hline $\mathrm{Ze}$ & $\begin{array}{l}0.121 \\
0.358\end{array}$ & $\begin{array}{l}0.088 \\
0.504\end{array}$ & $\begin{array}{c}0.696^{\star *} \\
0.000\end{array}$ & $\begin{array}{c}-0.379^{* *} \\
0.003\end{array}$ & $\begin{array}{c}0.530^{* *} \\
0.000\end{array}$ & $\begin{array}{l}0.067 \\
0.609\end{array}$ & $\begin{array}{c}0.695 \\
0.000\end{array}$ \\
\hline
\end{tabular}

1000-Grain weight (GW), Test weight (TW), Falling number (FN), Iron (Fe), Zinc (Zn)

"Significant at $5 \%$ level and " highly significant at $1 \%$ level.

Table 1: Correlation coefficients for qualitative traits in bread wheat under irrigated condition.

\begin{tabular}{|c|c|c|c|c|c|c|c|}
\hline & GW & TW & Protein & Starch & Gluten & FN & $\mathrm{Fe}$ \\
\hline TW & 0.013 & & & & & & \\
\hline P-Value & 0.922 & & & & & & \\
\hline Protein & $\begin{array}{c}-0.204 \\
0.117\end{array}$ & $\begin{array}{c}-0.228 \\
0.080\end{array}$ & & & & & \\
\hline Starch & $\begin{array}{c}-0.148 \\
0.259\end{array}$ & $\begin{array}{l}0.155 \\
0.238\end{array}$ & $\begin{array}{c}-0.483^{* *} \\
0.000\end{array}$ & & & & \\
\hline Gluten & $\begin{array}{c}-0.156 \\
0.234\end{array}$ & $\begin{array}{c}-0.234 \\
0.072\end{array}$ & $\begin{array}{c}0.629^{* *} \\
0.000\end{array}$ & $\begin{array}{c}-0.511^{* *} \\
0.000\end{array}$ & & & \\
\hline FN & $\begin{array}{c}-0.073 \\
0.581\end{array}$ & $\begin{array}{l}0.103 \\
0.434\end{array}$ & $\begin{array}{c}-0.294^{*} \\
0.022\end{array}$ & $\begin{array}{l}0.318^{*} \\
0.013\end{array}$ & $\begin{array}{c}-0.225 \\
0.084\end{array}$ & & \\
\hline $\mathrm{Fe}$ & $\begin{array}{l}0.001 \\
0.996\end{array}$ & $\begin{array}{c}-0.070 \\
0.594\end{array}$ & $\begin{array}{c}0.602^{*} \\
0.000\end{array}$ & $\begin{array}{c}-0.148 \\
0.260\end{array}$ & $\begin{array}{c}0.359^{* *} \\
0.005\end{array}$ & $\begin{array}{c}-0.128 \\
0.329\end{array}$ & \\
\hline $\mathrm{Ze}$ & $\begin{array}{l}0.026 \\
0.844\end{array}$ & $\begin{array}{l}0.036 \\
0.786\end{array}$ & $\begin{array}{c}0.564^{* *} \\
0.000\end{array}$ & $\begin{array}{c}-0.211 \\
0.105\end{array}$ & $\begin{array}{l}0.265^{\star} \\
0.041\end{array}$ & $\begin{array}{c}-0.150 \\
0.252\end{array}$ & $\begin{array}{c}0.593^{* *} \\
0.000\end{array}$ \\
\hline
\end{tabular}

1000-Grain weight (GW), Test weight (TW), Falling number (FN), Iron (Fe), Zinc (Zn)

*Significant at $5 \%$ level and ${ }^{* *}$ highly significant at $1 \%$ level.

Table 2: Correlation coefficients for qualitative traits in bread wheat under rainfed condition. 
Citation: Abdullah M, Ahmad J, Javed A, Hussain M, Shamim S, et al. (2018) Nutritive Appraisal of Various Wheat Varieties/Lines for Developing Biofortified Wheat (Triticum Aestivum L.). J Food Process Technol 9: 743. doi: 10.4172/2157-7110.1000743

Page 3 of 4

\begin{tabular}{|c|c|c|c|c|c|c|c|c|}
\hline \multicolumn{9}{|c|}{ Cluster Centroids } \\
\hline \multirow{2}{*}{ Variables } & \multicolumn{2}{|c|}{ Cluster-1 } & \multicolumn{2}{|c|}{ Cluster-2 } & \multicolumn{2}{|c|}{ Cluster-3 } & \multicolumn{2}{|c|}{ G. Centroid } \\
\hline & Irrigated & Rainfed & Irrigated & Rainfed & Irrigated & Rainfed & Irrigated & Rainfed \\
\hline Grain Wt (grams) & 35.855 & 37.400 & 37.998 & 36.971 & 37.12 & 37.690 & 36.746 & 37.251 \\
\hline $\begin{array}{c}\text { Test Wt } \\
\text { (kg/hl) }\end{array}$ & 69.455 & 75.611 & 69.786 & 75.479 & 70.91 & 74.437 & 69.697 & 75.249 \\
\hline $\begin{array}{c}\text { Protein } \\
(\%)\end{array}$ & 14.808 & 14.711 & 14.489 & 14.977 & 14.59 & 15.190 & 14.673 & 14.968 \\
\hline $\begin{array}{c}\text { Starch } \\
(\%)\end{array}$ & 54.523 & 54.425 & 54.784 & 54.190 & 54.64 & 53.737 & 54.628 & 54.132 \\
\hline $\begin{array}{c}\text { Gluten } \\
(\%)\end{array}$ & 28.121 & 27.321 & 27.909 & 28.097 & 26.70 & 28.867 & 27.925 & 28.108 \\
\hline Falling No.(Sec) & 597.788 & 660.964 & 478.114 & 565.210 & 696.80 & 463.633 & 562.158 & 562.158 \\
\hline $\begin{array}{c}\mathrm{Fe} \\
(\mathrm{ppm})\end{array}$ & 37.742 & 38.768 & 37.205 & 39.645 & 38.30 & 39.500 & 37.592 & 39.408 \\
\hline $\begin{array}{c}\mathrm{Zn} \\
(\mathrm{ppm})\end{array}$ & 31.842 & 32.400 & 31.825 & 32.447 & 31.86 & 32.620 & 31.837 & 32.479 \\
\hline
\end{tabular}

Table 3: Cluster analysis of wheat varieties/lines under irrigated and rainfed conditions.

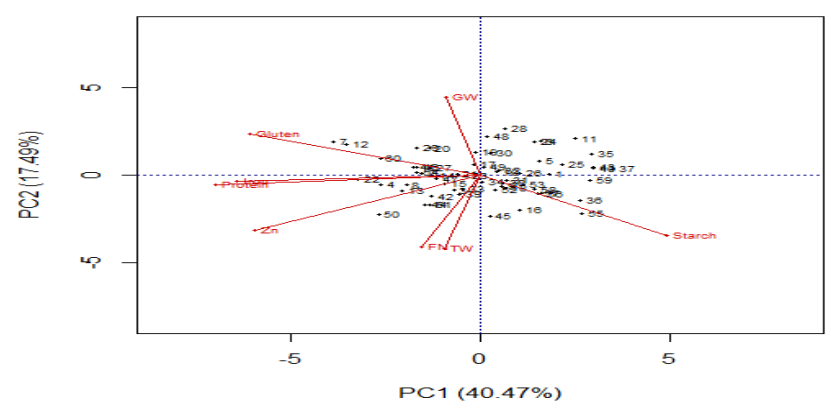

Figure 1: Biplot of wheat varieties/lines under irrigated condition.

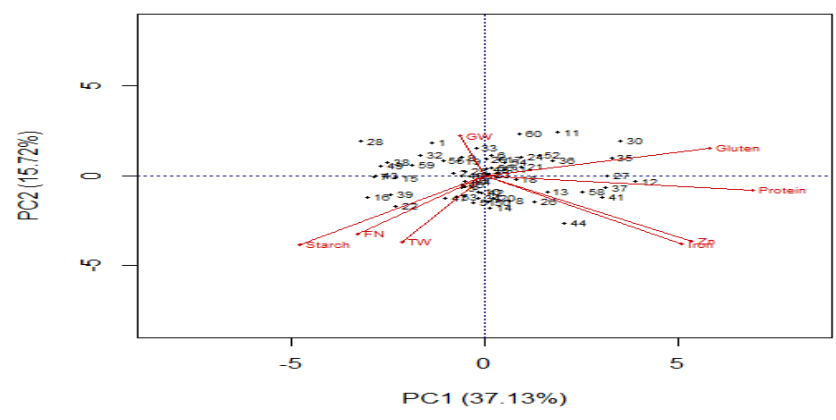

Figure 2: Biplot of wheat varieties/lines under rainfed condition.

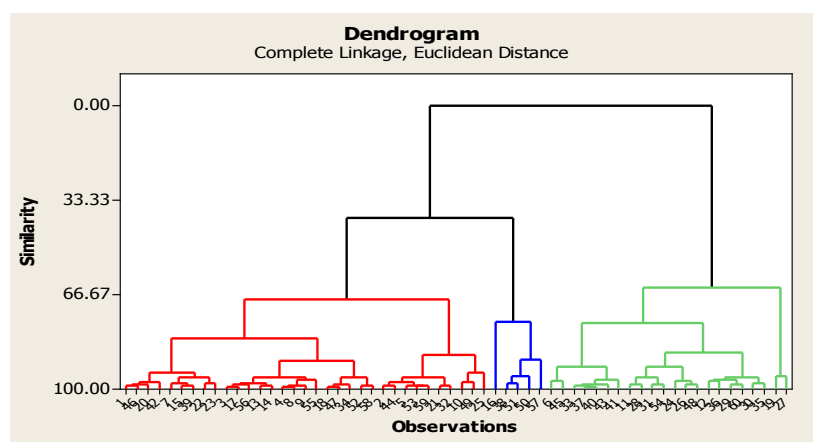

Figure 3: Dendrogram of wheat varieties/lines under irrigated condition.

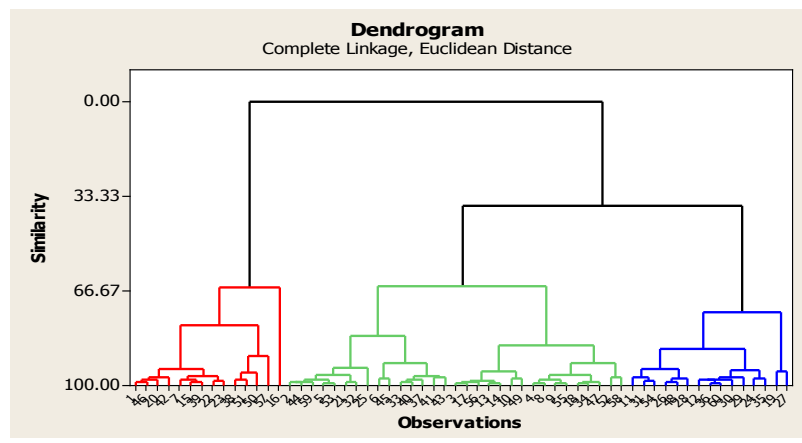

Figure 4: Dendrogram of wheat varieties/lines under rainfed condition.

represent $23 \%, 52 \%$ and $25 \%$ of total genotypes, respectively. Cluster 1 exhibited relatively high value of test weight. Cluster 2 had high value of Fe. Cluster 3 represented relatively high value of grain weight, protein, gluten and $\mathrm{Zn}$ while lowest value of falling number (Table 3). To cover iron and zinc deficiency among vulnerable population, it is the need of the time to fortify wheat flour with iron and zinc. Moreover, Blackstrap molasses may be added in the bakery products to replace their sugar contents and also to improve their iron content. Among other techniques best preferred approach is to develop wheat varieties containing high iron and zinc content [13]. For this purpose, various wheat varieties/lines are being screened for iron and zinc contents to develop bio-fortified wheat.

\section{Conclusion}

The analysis revealed that 1000 grain weight was higher (23.9$50.2 \mathrm{~g})$ in irrigated than the rainfed condition (31-42.0 g) while test weight was found to be lower in irrigated condition (59.9-75.8) higher in rainfed condition $\left(64.5-79.9 \mathrm{Kg} \mathrm{hl}^{-1}\right)$. Protein, gluten, and starch content ranged between 12.0-16.1, 13-16.2, 21-34 \& 21-38 and 51.857.1 and $51.9-56.1 \%$ in irrigated and rainfed trials, respectively. Falling No. values were remained the same in both condition $(352-814 \mathrm{sec})$ Most of the varieties/lines had narrow range of $\mathrm{Zn}$ (31-32.6 \& 31.2-33.9) and $\mathrm{Fe}(35-40 \& 35-43 \mathrm{ppm})$ in irrigated and rainfed trial, respectively. Statistical analysis of both sets showed gluten \& protein being directly correlated to each other, showing a positive correlation with $\mathrm{Fe} \& \mathrm{Zn}$ but a negative one with starch. In both sets, a direct correlation of falling No. with starch was observed only in rainfed set. In irrigated, conditions, cluster 3(5 genotypes) represented relatively high value of 
Citation: Abdullah M, Ahmad J, Javed A, Hussain M, Shamim S, et al. (2018) Nutritive Appraisal of Various Wheat Varieties/Lines for Developing Biofortified Wheat (Triticum Aestivum L.). J Food Process Technol 9: 743. doi: 10.4172/2157-7110.1000743

Page 4 of 4

Fe and $\mathrm{Zn}$ contents while in rainfed condition, cluster 2 (31 genotypes) and cluster 3(15 genotypes) represented relatively high value $\mathrm{Zn}$. To overcome iron and zinc deficiency among defenseless population, there could be several approaches such as fortifying wheat flour with iron and zinc, adding blackstrap molasses in the bakery products, however, the most preferred and sustainable option is the development of bio fortified wheat varieties and makes those available to the vulnerable masses.

\section{Acknowledgment}

The authors are thankful to statistical section, Ayub Agriculture Research Institute, Faisalabad, Pakistan.

\section{References}

1. Government of Pakistan (2016-2017) Pakistan Economic Survey

2. FAO (2013) Economic and social development department country cerea balance.

3. Borrill P, Connorton JM, Balk J, Miller AJ, Sanders D, et al. (2014) Biofortification of wheat grain with iron and zinc: integrating novel genomic resources and knowledge from model crops. Front Plant Sci 5: 53

4. Alina T, Lazureanu $A$ (2011) The influence of dose fertilizer on the qualitative corn hybrid Pr35P12. J Hortic For Biotechnol 15: 215-217.

5. Methods Technical Leadership Committee (2010) Approved methods of the American association of cereal chemists, Method 38-12A. (11 th edtn), St. Paul, MN, USA.
6. Methods Technical Leadership Committee (2010) Approved methods of the American association of cereal chemists, Method 56-81B. (11 th $e d t n)$, St. Paul MN, USA.

7. Cook KK (1997) Extension of dry ash atomic absorption and spectrophotometric methods to determination of minerals and phosphorus in soy-based, wheybased, and enteral formulae (modification of AOAC Official Methods 985.35 and 986.24): collaborative study. J AOAC Int 80: 834-844.

8. Naz G, Akmal M (2016) Yield and yield contributing traits of wheat varieties as affected by nitrogen rates. Sarhad J Agric 3: 212-217.

9. Bulusu S, Laviolette L, Mannar V, Reddy V (2006) Cereal fortification programmes in developing countries. Issues in complementary feeding, issues in complementary feeding. Nestlé nutrition workshop series pediatric program 60: 91-105.

10. Zhao FJ, Su YH, Dunham SJ, Rakszegi M, Bedo Z, et al. (2009) Variation in mineral micronutrient concentrations in grain of wheat lines of diverse origin. $J$ Cereal Sci 49: 290-295.

11. Velu G, Ortiz-Monasterio I, Singh RP, Payne T (2011a) Variation for grain micronutrients concentration on wheat core-collection accessions of diverse origin. Asian J Crop Sci 3: 43-48.

12. Velu G, Singh RP, Huerta-Espino J, Peña RJ (2011b) Breeding for enhanced zinc and iron concentration in CIMMYT spring wheat germplasm. Czech J Genet Plant Breed 47: 174-177.

13. Cakmak I (2008) Enrichment of cereal grains with zinc: agronomic or genetic bio fortification. Plant Soil 302: 1-17. 